UDC 004.932.2:343.533

O.V. Narimanova, $\mathrm{PhD}$

Odessa National Polytechnic University, 1 Shevchenko Ave., 65044 Odessa, Ukraine; e-mail: semejka@ua.fm

\title{
DEVELOPMENT OF ANTI-COUNTERFEIT CONSUMER PRODUCT AUTHENTICATION SYSTEM
}

О.В. Наріманова. Розробка противоконтрафактної системи перевірки продукції. Метою дослідження є розробка противоконтрафактної системи перевірки продукції. Сформульовано основні вимоги до зазначеної системи, обгрунтовано вибір методу перевірки автентичності продукції. На основі запропонованого раніше методу перевірки цілісності та автентичності QR-коду розроблено схему противоконтрафактної системи перевірки продукції. Запропонована в рамках системи технологія перевірки продукції є простою, економною в реалізації, не потребує зовнішньої зміни упаковки продукції, не порушує існуючий виробничий процес. Розроблена технологія може бути рекомендована для використання власними підприємствами та державними установами, які зацікавлені в захищеності своєї продукції від підробки, а також у відстеженні і вилученні з обігу контрафактної продукції.

Ключові слова: противоконтрафактна система, перевірка продукції, QR-код, перевірка цілісності, перевірка автентичності.

O.V. Narimanova. Development of anti-counterfeit consumer product authentication system. Aim of the research is to develop an anti-counterfeit consumer product authentication system. The main requirements for this system are formulated, the choice of method of consumer product authentication is substantiated. The scheme of anti-counterfeit consumer product authentication system is developed basing on previously proposed method of checking the QR-code integrity and authenticity. The proposed within the system consumer product authentication technology is simple, economical for implementation, does not require the external changes of product packaging, does not affect existing production process. The technology can be recommended for the use to private businesses and government institutions that are interested in the security of their products from counterfeiting, as well as tracking and removing from circulation the counterfeit consumer products.

Keywords: anti-counterfeit system, product authentication, QR-code, integrity checking, authenticity checking.

Introduction. Today the problem of counterfeit consumer products detection and prevention goes far beyond this one of manufacturers economic losses and shadow economy suppression issues, since the counterfeit products pose a risk to the consumers health and lives. A simple and reliable way to verify the products originality, available to the end user, can generally solve all the problems associated with the counterfeit products circulation. In this regard an urgent task of developing anticounterfeit products authentication system for the end consumer use arises.

Literature review. Every year rapidly increasing is the number of counterfeit goods ranging from counterfeit drugs up to counterfeit designer products that serves to the prosperity of this illegal economy sector. According to the Organization for Economic Cooperation and Development data, the cost of counterfeit consumer products that crossed international borders in 2007 is estimated as more than 250 billion USD. This is significantly higher than in other illegal economy areas, such as arms smuggling or human trafficking. By the International Chamber of Commerce forecast in 2015 the counterfeit products global volume will exceed 1,7 trillion USD that is more than $2 \%$ of total global production output [1].

However, the main problem of counterfeit consumer products wide circulation relates not only to the significant revenue of these goods producers. The use of dangerous and substandard products exposes to risk the consumers health and in some cases even life. Characteristic examples here include fatal doses of melanin in baby food, the presence of carcinogenic dyes in consumer products, drugs containing reduced quantities of active substance or aviation spare parts causing the accidents and non-standard electric wires that lead to a fire [1].

DOI 10.15276/opu.2.46.2015.22

(C) 2015 The Authors. This is an open access article under the CC BY license (http://creativecommons.org/licenses/by/4.0/). 
Currently, the fight against production and distribution of counterfeit consumer products embraces four main areas [1]:

- legislative measures to create and pass laws that protect intellectual property rights and apply punitive sanctions against counterfeit products manufacturers and distributors;

- national customs organizations activities preventing the counterfeit consumer products flow into the country, as well as strengthening local and federal laws that destroy chains of counterfeit goods distribution;

- private business efforts for the establishment of counterfeit-preventing technologies and systems to protect the authenticity of their products, including anti-counterfeit technologies as well as products identification and tracking;

- national and international standards development to support private business and governmental agencies.

The development of anti-counterfeit technologies and systems for products identification and tracking is the most promising among these areas.

Aim of the Research is to develop an anti-counterfeit product authentication system.

To achieve that goal we need to:

- formulate the basic requirements to such a system;

- substantiate the choice of software and method of product authentication;

— determine the system hardware components;

- determine the system operation process.

Main body. Currently, the main measures against the counterfeit products that apply manufacturers can be divided into the following groups:

- periodic change of appearance of the products packaging;

- use of holographic images, still their manufacturing and use increase the production cost;

- use of identifying data when to verify the product authenticity the consumer must perform additional steps such as sending a text message or searching information on the Web etc.

General shortcomings of these measures are:

- such measures implementation increases the cost of production;

- there is a need to inform consumers on methods to verify the products authenticity and the product package change through advertising;

- complexity of product authentication.

In this regard, the basic requirements for the anti-counterfeit product authentication system consist in:

- economical and simple system implementation that may interest the producer;

- this system use simplicity, reliability and clarity for the consumer.

To date, QR-codes are widely used. And almost all printed information (advertising and information posters, labels of various products, announcements, etc.) is duplicated using QR-codes or is accompanied with them. QR-codes do contribute to the variety of human activities, both at home and at work. They are used for various business purposes at factories, companies, logistical operations running, representing therefore an indispensable, convenient and familiar to users tool.

In this regard, the development of anti-counterfeit consumer product authentication system involving QR-code is considered as a reasonable step. Checking the integrity and authenticity of the QRcode on the product label can be equivalent to the product authentication test.

In addition, there exists a method of digital watermarking to authenticate and verify the integrity of QR-code using a mobile device [2, 3]. That method satisfies the requirements specified below.

- Usage of digital watermark technology does not prevent the QR-code reading with standard tools. Regardless of whether the user involves special software to verify the QR-code integrity and authenticity, he can read data with standard tools.

- The used method is resistant to such processes as code printing and reading with a mobile device camera. In most cases the QR-code is printed and then is read with the mobile device camera that leads to the inevitable noises at printing and scanning (camera reading) that can significantly distort 
the features that are used to verify the QR-code integrity and authenticity. However, it should be noted that due to QR-code specific structure, such noises do not affect the possibility of QR-code reading. That's why it is so important to use the resistant method of watermarking.

- The developed technology is cost-effective, because its implementation requires a change in QR-code only on the product label. So, its implementation does not require additional materials or equipment.

Results. Based on the analysis of the current technology state and available systems for products authentication and protection from counterfeiting, as well as on the formulated requirements to these systems, a principal scheme of anti-counterfeit product authentication system through the QR-code verification is developed (Fig. 1).

The hardware necessary to implement an anti-counterfeit product authentication system on the basis of integrity checking and authentication of QR-code on the manufacturer side is a PC operating the software that generates QR-code and implements the insertion of digital watermark. After QRcode is generated and watermarked it is applied to the label, printed by standard means.

On the consumer side the necessary hardware components include a mobile device (smartphone, tablet, etc.) with software for authentication of digital watermark along with the QR-code. That software is expected to be available in the Internet and /or distributed in other way by the products manufacturer.

The operation of anti-counterfeit product authentication system involves the following steps:

- using the developed software, the manufacturer generates a QR-code with digital watermark and places it on the product label (none additional preconditions for the product labels printing process arise);

- the manufacturer distributes to the consumer the software for verifying the QR-code integrity and authenticity (the most convenient shall be the specified software allocation at the manufacturer official website or at the marketing network);

- before consumer purchases the product, he uses his mobile device (which can be not connected to the Internet) with received software to read QR-code with automatic verification of QR-code integrity and authenticity (by checking the digital watermark);

- when such QR-code integrity and authenticity checking has positive result the product is considered authentic and therefore is advisable to purchase as original one. In the case of negative result of such checking the consumer receives appropriate message, and software registers the counterfeit product location; so at next internet connection the mobile device shall inform the manufacturer about the fact of revealing and the positioning of the counterfeit consumer products.

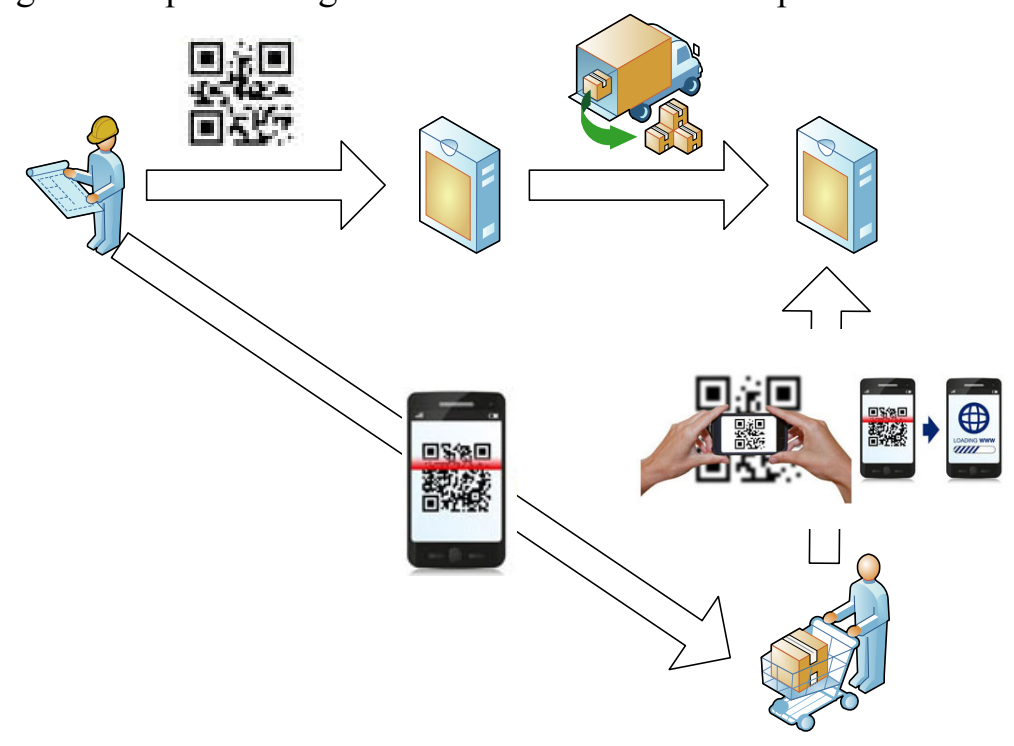

Fig. 1. Principal scheme of anti-counterfeit product authentication system on the basis of QR-code integrity and authenticity checking 
Conclusions. The proposed technology implementation is inexpensive, because:

- there is no need to spend money for additional expensive materials, holographic images, etc., because to protect the product QR-code is used only;

- instead of traditionally practiced changes in the packaging and/or packing materials, the QRcode should be changed only;

- the proposed anti-counterfeit product authentication system implementation does not require any specialized equipment and never violates the existing production process.

Using special software the consumer can quickly and easily check the products originality. In case the counterfeit products detection, the manufacturer and/or supervising authority are automatically notified about the counterfeit products presence and location. The elaborated technology can be recommended for use by business owners and governmental agencies interested in their products protection against counterfeiting by tracking and removal from circulation of such counterfeit products, as well as in their clientele protection against poor-quality products.

\section{Література}

1. Гасёровски-Денис, Э. Наступление на контрафакт [Електронний ресурс] / Э. Гасёровски-Денис // ИСО - Международная организация по стандартизации. Разработчик и издатель международных стандартов. - 2014. - Режим доступу: http://www.iso.org/iso/ru/news.htm?refid=Ref1809 (Дата звернення: 24.04.2015).

2. Наріманова, O.B. Метод захисту QR-коду з використанням цифрового водяного знаку / О.В. Наріманова, Д.М. Семенченко // Інформатика та математичні методи в моделюванні. 2013. 一 T. 3, № 4. - C. $361-368$.

3. Наріманова, O.В. Перевірка цілісності та автентичності QR-коду / O.В. Наріманова // Тези доповідей X Міжнародної науково-практичної конференції «Військова освіта і наука: сьогодення та майбутнє». - К.: ВІКНУ, 2014. - С. 63.

\section{References}

1. Gasiorowski-Denis, E. (2014). Crackdown on counterfeiting. ISO - International Organization for Standardization. Retrieved from http://www.iso.org/iso/home/news_index/news_archive/news.htm?refid=Ref1809

2. Narimanova, O.V. and Semenchenko, D.M. (2013). Digital watermarking approach for QR-code protection. Informatics and Mathematical Methods in Simulation, 3(4), 361-368

3. Narimanova, O.V. (2014). Authenticity and integrity verification of QR-code. In Proceedings of X International Scientific Conference "Military Education: Present and Future" (p. 63). Kyiv: Military Institute of Taras Shevchenko National University of Kiev. 